\title{
WORKMEN'S COMPENSATION AWARDS FOR PSYCHONEUROTIC REACTIONS*
}

THE question of whether and under what circumstances a worker insured under workmen's compensation should be allowed disability payments for a psychoneurotic reaction has been presented to judges and administrative boards with increasing frequency in recent years. Existing doctrines governing the award of disability payments under workmen's compensation statutes are in many cases unsuitable for dealing with this form of disturbance. This Comment will attempt to reevaluate these doctrines in the light of psycho-analytic theories explaining the causes, essential nature, and symptoms of psychoneurotic reactions. It will further evaluate the effect of compensating psychoneurotic injuries on the employee and his disturbance. ${ }^{1}$

\section{The Award of Compensation}

Workmen's compensation statutes generally provide for monetary awards and medical benefits to employees or their dependents in case of a disabling injury by accident arising out of and in the course of employment. ${ }^{2}$ This system developed in reaction to the inadequacy of recovery under common law tort doctrines and procedures. ${ }^{3}$ It had been found that under tort law

a) large portions of all fatal and non-fatal injuries remained uncompensated, b) the sums actually paid were frequently inadequate token compensation, c) recoveries were obtained only after protracted litigation, d) the attorneys of the injured workmen retained a large share of the sum actually obtained, [and] e) an undue portion of the premiums paid by industry went to the insurance companies for profits, administrative costs and profits, and was thus socially wasted. ${ }^{4}$

Workmen's compensation statutes reject the common law defenses of contributory negligence, fellow-servant, and assumption of risk in favor of a general theory of liability without fault. 5 The right to an award, and its amount,

*An earlier version of this Comment was submitted in satisfaction of the writing requirement of the Yale Law School's Divisional Program, Law and the Behavioral Sciences Division, 1960-1961. The Law Journal wishes to thank Professor Richard C. Donnelly for bringing this paper to the Editors' attention.

1. The discussion in this Comment although limited to psychoneurotic reactions, could be applied as well to psychotic reactions, which are more serious forms of reactions. On psychotic reactions see generally, ENGLish \& Finch, Introduction to Psychiatry 4344, 332-423 (2d ed. 1957) [hereinafter cited as ENGLISH \& FINCH].

2. See generally 1 \& 2 LARSON, WORKMEN's COMPENSATION LAW (1952) [hereinafter cited as Larson]; Schneider, Workmen's Compensation Text (1941-60) [hereinafter cited as Schneiner's Text] ; Schnemer, Workmen's Compensatron Statutes (19391949).

3. See, c.g., New York Cent. R.R. v. White, 243 U.S. 188 (1917).

4. Rresenfeld \& Maxwell, Modern Soctal Legislation 137 (1950).

5. See, e.g., New York Cent. R.R. v. White, 243 U.S. 188 (1917) (upholding constitutionality of liability without fault in a compulsory act), and Hawkins v. Bleakly, 243 
is initially determined by a workmen's compensation board or state court. ${ }^{6}$ Awards are paid out of various forms of insurance funds, financed by the employer through the payment of regular premiums to a state fund or to private companies or through regulated self-insurance. ${ }^{7}$

The underlying goals of the workmen's compensation system are 1) to compensate the worker, his dependents, or survivors for at least part of the wage loss and medical expenses incurred as a result of industrial injury, ${ }^{8} 2$ ) to rehabilitate the employee so that he can re-enter the labor force and again become a productive member of the community, ${ }^{9}$ and 3 ) to provide a monetary incentive to the employer to minimize occupational injury. ${ }^{10}$ There are two principal limitations on recovery: injury must result in a disability entailing total or partial incapacity to work, ${ }^{11}$ and the injury must "arise out of and in the course of employment." 12 For purposes of determining whether psychoneurotic injuries are compensable, these goals and limitations of workmen's compensation will be accepted as given.

U.S. 210 (1917) (elective act). However, several defenses, such as intoxication or intent to injure self or another, are generally available to the employer. See, e.g., N.Y. WoRKMEN'S COMP. ACT $\$ 10$.

6. In the majority of states, a workmen's compensation board makes the initial finding. See, e.g., N.Y. WorkMren's CoMp. LAw \& 141. A small minority, however, have court administration in the first instance. See, e.g., ALA. CODE tit. 26, $\$ 297$ (1958). For a consideration of judicial review of compensation awards, see 2 LARsoN $\$ \$ 80.00$ to .42 (1952).

7. See Somers \& Somers, Workmen's Conspensation 93-142 (1954) [hereinafter cited as SOMERS \& SoMIERs]; 2 LaRson $\$ \$ 92.00$ to .32 .

8. The intent of the legislators was to prevent the employee and his dependents from becoming public charges. Baltimore Steel Co. v. Burch, 49 A.2d 542, 544 (Md. 1946). But full wage loss compensation was not intended. Depending upon the degree of incapacity and its duration, a disability is classified as total or partial, and temporary or permanent. To limit the amount of remuneration, statutory maximums have been imposed on the period of time and the percentage of prior wages which may be paid. In addition, the dollar amount per week is limited as well as the total amount of compensation. See generally 2 LARsoN $\$ \$ 57.00,61.20$.

Most states, in addition to providing for compensation, allow the employee to recover the cost of reasonable medical expenses. See, e.g., Conn. GEn. Stat. Ann. § 31-157 (1958); Hawait Rev. Laws § 97-22 (1955); Neb. Rev. Stat. Ann. § 48-120 (1943). Several states, however, impose a period of limitations and a maximum amount. See, c.g., ArA. Code tit. 26, \& 293 (1958) (6 months- $\$ 1200$ ); Tenn. Code ANN. $\$ 50-1004$ (1955) (1 year-\$1500). See generally 10 ScHNEIDER's TEXT $\$$ 2001-47.

9. Most statutes provide for vocational rehabilitation. See, e.g., ArIz. REv. StAt. ANs. $\S \S 23-501$ to -508 (1956) (amount is in commission's discretion); HAwaII REv. LAwS $\S 97-26.5$ (1955) (up to $\$ 1,000$ for permanently disabled persons).

10. Three devices have been advanced in an attempt to promote injury prevention: 1) merit rating which is designed to reward firms with favorable injury experience by allowing reductions in premiums; 2) penalties on employers in the form of increased compensation when an injury results from a violation of a safety code; and 3) accident reporting which provides a basis for investigation and control. For a criticism of these devices in aiding prevention, see SoMrers \& Somers 197-235 (1954).

11. See notes 32-34 infra and accompanying text.

12. See notes 87-100 infra and accompanying text. 


\section{The Disability Requirement}

A psychoneurosis is a mental disorder which is dependent on unconscious mental causes. ${ }^{13}$ In finding solutions to his unconscious problems, the individual develops personality difficulties which, in terms of the individual's adaptation to reality, may be considered to lie somewhere between the reactions and adjustment mechanisms of the "average" and the psychotic individual. ${ }^{14}$ Although the sufferer is able to adapt to his social environment, his ego is "warped and distorted."15 The main characteristic of a psychoneurotic reaction is the development of "anxiety" which may be expressed directly or in a number of substitute ways since the ego attempts to control anxiety by the use of psychological defense mechanisms. ${ }^{16}$ The various ways employed by the individual to cope with his anxiety give rise to six principal types of psychoneurotic reaction. ${ }^{17}$ An anxiety reaction is expressed by a diffuse and constant anxiety not related to particular situations or objects. ${ }^{18}$ Associated symptoms of the anxiety reaction include lack of concentration, depression, irritability, and excitability. ${ }^{19}$ A phobic reaction results when the anxiety evoked by a specific idea, object, or situation encountered in daily life is displaced by an intense fear of an idea or situation which has symbolic significance. ${ }^{20}$ The sufferer is driven to near

13. See generally Fenichel, The Psychoanalytic Theory of the Neuroses (1945) [hereinafter cited as Fenichel]; Deutsch, Psychoanalysis of the Neuroses (1933); English \& Finch 139-231; Henderson \& Gillespie, A Textbook of Psychiatry 146226 (7th ed. 1955) [hereinafter cited as Henderson \& Gillespie].

14. Noyes \& Kolb, Modern Cinnicar, Psychiatry 490-94 (5th ed. 1958) [hereinafter cited as Noyes \& KoLB]. A general definition of "average," "normal" or "healthy" has not been developed. See, e.g., Hartmann, Psychoanalysis and the Concept of Health, INT'L J. of Psychoanalysis XX, (1939) ; Glover, Medico-Psychological Aspects of Normality, Brit. J. of Psychozogy XXII (1932); and Jones, The Concept of $A$ Normal Mind, INT' J. of Psychoanalysis XXIII (1942).

The psychoses involve far more serious personality disruptions than do the psychoneuroses. "In the typical psychoses the individual has lost his contact with reality and reveals severe disturbances in all areas of his life." ENGLISH \& FINCH 43.

15. ENGLISH \& FINCH 44. The ego "contains the compromising, solution-forming and defense-creating aspects of the personality. It evaluates situations and forms judgments. The ego organization, being in charge of such important functions as perception, memory, reality evaluating and testing, synthesizing of experience and of acting as intermediary between the inner and outer world, may be regarded as the integrative and executive agency of the personality." Noyes \& KoLB 33.

16. American Psychiatric Association, Diagnostic \& Statistical ManualMental Disorders 31-32 (1952) [hereinafter cited as Psychiatric Manual].

17. The classification of psychoneuroses in terms of reactions seems to be the most fruitful means of viewing the psychoneurotic disorders, for the individual who develops a psychoneurosis is reacting to various stresses in a manner which is an exaggeration of the "normal" mode of behavior rather than exhibiting a mental disease. Noyss \& KoLB 83. Clinically, there are no sharply defined lines among the psychoneuroses, and frequently the individual will exhibit manifestations of several reactions in varying degrees. Noyes $\&$ Kolb 494. Compare Henderson \& Giliespie 49.

18. ENGLISH \& FinCH 140.

19. Henderson \& Gillespie 166-78; Noyes \& Kolb 498-99.

20. Psychiatric Manual 33. 
panic whenever he encounters his phobic situation. ${ }^{21}$ An obsessive-compulsive reaction is similarly linked to particular objects or contexts, but is evidenced by "unwelcome repetitive ideas or impulses to perform ritualistic acts." 22 In a conversion reaction the individual expresses his unconscious conflicts through symbolic functional disturbances in parts of the body, usually those that are mainly under voluntary control. ${ }^{23}$ Examples are sudden paralysis of an extremity, or total incapacitation of one of the senses such as seeing or hearing, accompanied by a calm and unconcerned attitude termed belle indifférence. ${ }^{24}$ The dissociative reaction manifests itself by the individual's "walling off certain areas of the mind from consciousness," 25 resulting in various episodic mental states such as fugues, ${ }^{26}$ somnambulisms, ${ }^{27}$ dream-states, amnesias or multiple personality. ${ }^{28}$ In a depressive reaction, the anxiety is partially relieved by a "chronic state of dejection or despondency accompanied by a tendency toward self-depreciation." 29

Any of these syndromes can result in either a partial or total inability of the individual to perform some or all of his normal activities. For example, if a particular job involves contact with a situation to which a phobia has become attached, the panic which ensues may completely destroy the individual's ability to perform the work involved. ${ }^{30}$ Although the layman may view the anxiety as unrealistic, the disturbance which the individual experiences is not imaginary. The incapacity is as real as that resulting from a "physical" injury. ${ }^{31}$

Not all psychoneuroses will be compensable under a workmen's compensation statute. Workmen's compensation awards are not made for injury as such, but for inability to perform or to obtain work produced by such injury. ${ }^{32} \mathrm{~A}$

21. ENGlish \& Fincer 191-96; Noyes \& Kolb 501-02.

22. See Engitsh \& Finch 205. See generally Freud, Notes Uton A Case of Obsesstonal Neurosis, in 3 Collected Papers (1949).

23. Psychiatric Manual 32-33.

24. English \& Fince 158-79; Noyes \& KolB 504-05.

25. English \& Finch 180. See generally Prince, The Dissociation of A PersonALITY (1925).

26. A fugue is a state of psychological amnesia, in which the individual may appear to possess all his mental faculties, but in actuality is either partially or totally incapable of recalling certain experiences. Hinste \& Casrpbeld, Psychiatric Dictionary 309 (1960) [hereinafter cited as FinsIE \& CAXIPBELL].

27. Somnambulisms are dissociated states identical with fugues except that they begin during sleep and manifest themselves in sleepwalking. Hinste \& CAMPBDEL 684.

28. The latter phrase describes the formation of secondary personalities which escape the ordinary repression mechanisms and temporarily control the individual. The secondary personalities possess distinct characteristics operating independently of each other and with complete ignorance of the existence of both the primary personality and the other subpersonalities. Henderson \& GILLESPIE 127, 192.

29. ENGLISH \& FINCH 221.

30. Noyes \& KoLB 501-02.

31. HeNderson \& Gillespie 148.

32. The degree of disability depends upon the inability to perform or to obtain work. Functional impairment is a necessary but not sufficient condition for an award. An injury resulting in sexual impotency, for example, is not compensable, for the injury does not 
psychoneurosis will be compensable, therefore, only when it affects the worker's earning capacity.

The necessity of translating psychiatric terminology and concepts into legally meaningful economic terms presents a danger that the psychiatrist will be called upon to make decisions beyond his special competence. Workmen's compensation boards are dependent upon psychiatrists to provide information as to the genuineness, cause, severity, duration and extent of the injury. But psychiatrists are not qualified to estimate the percentage of normal earning capacity which has been lost due to the injury. This decision requires familiarity with a myriad of industrial practices and employment opportunities. ${ }^{33}$ It also requires determinations involving the reasonableness of alternatives and substitutes open to the claimant, ${ }^{34}$ social value judgments which seem peculiarly within the competence of the legal tribunal. ${ }^{35}$

In addition, the psychiatrist may be restricted as to the information he can give within his own area of competence. A disability award typically requires an estimation of the duration and severity of the illness for the purpose of calculating the duration and amount of payments. ${ }^{36}$ But accurate prognosis of the

affect ability to obtain or hold a job. Except for schedule injury provisions, which catalogue rates for loss of specific members of the body irrespective of loss of earning capacity, the degree of disability is presumptively determined by comparing pre-injury earnings with post injury earning ability.

33. For example, earning capacity is determined by selecting a base period of time and discounting such factors as change in general wage levels since the accident, see, e.g., Whyte v. Industrial Comm'n, 227 P.2d 230 (Ariz. 1951) ; Artac v. Union Collieries Co., $149 \mathrm{~Pa}$. Super. 449, 27 A.2d 782 (1942); changes in claimant's age, Malcolm v. Bowhill Coal Co., [1910] Sess. Cas. 447 (Scot 1st Div.); training, Ludwickson v. Central States Elec. Co., 142 Neb. 308, 6 N.W.2d 65 (1942) ; hours of work, Devlin v. Iron Works Creek Constr. Corp., $164 \mathrm{~Pa}$. Super. 481, 66 A.2d 221 (1949); and payment of disproportionate wages because of employer's sympathy, Hartford Acc. \& Indem. Co. v. Hoage, 85 F.2d 420 (D.C. Cir. 1936) ; Trinity Universal Ins. Co. v. Rose, 217 S.W.2d 425 (Tex. Civ. App. 1949).

34. Generally courts hold that the post-injury earnings may result from any kind of employment. See, e.g., Clark v. Henry \& Wright Mfg. Co., 136 Conn. 514, 72 A.2d 489 (1950). However, some courts require that the earning capacity be in the same employment. Allen v. National Twist Drill \& Tool Co., 324 Mich. 660, 37 N.W.2d 664 (1949); Honeycutt v. Carolina Asbestos Co., 235 N.C. 471, 70 S.E.2d 426 (1952) (special statutory provision for disability for asbestosis or silicosis), or in work of any reasonable character, Washington v. Independent Ice \& Cold Storage Co., 211 La. 690, 30 So. 2d 758 (1947). Despite sporadic earnings, a worker may be found totally disabled if his physical condition disqualifies him for regular employment. Similarly, the worker's inability to obtain work because of his injury will support a total disability award although he is medically able to function on a job. See, e.g., Czeplicki v. Fafnir Bearing Co., 137 Conn. 454, 78 A.2d 339 (1951) ; Leonardo v. Uncas Mfg. Co., 75 A.2d 188 (R.I. 1950).

35. See generally Goldstein \& Katz, Dangeronsness and Mental Illness, Some Observations on the Decision to Release Persons Acquitted by Reason of Insanity, 70 YALE L.J. 225 (1960) (allocation of responsibility for decision-making between the psychiatrist and the court).

36. Compensation is generally awarded for a specified percentage of disability for a fixed number of weeks, with the employer and employee both having the right to reopen the award for changed conditions. See, e.g., N.Y. Workaren's Conrp. LAw \& 15. 
duration and severity of an individual psychoneurotic reaction may often be impossible. A prognosis must be based upon detailed information regarding the past experiences of the individual, his present reactions and adjustments, and the environmental factors which may affect him in the future. ${ }^{37}$ In addition to the possibility that there may not be enough time to compile sufficient data, psychiatric prognosis is made inherently unreliable by the fact that unforeseen factors may arise during the course of therapy which sustain or alleviate the psychoneurosis. These factors may consist of changes in the patient's life situation, for example death of a close relative, or newly acquired insights into the patient's mental state, such as the discovery of a hidden psychosis or unusual attributes. ${ }^{38}$

In some cases it may even be difficult to obtain an adequate medical diagnosis of the causes and present condition of a psychoneurotic injury. Some employees suffering from a psychoneurotic reaction may refuse to undergo examination, ${ }^{39}$ or may not cooperate sufficiently. Moreover, a reliable psychiatric diagnosis may require a lengthy investigation to acquire the necessary information regarding the individual's past experiences. ${ }^{40}$ The expense of such examinations may create additional obstacles to accurate diagnosis. Ordinarily, the cost of initial medical examination is borne by the employer. ${ }^{41}$ Presumably, this obligation includes the duty to provide psychiatric diagnosis when it is needed. But because of ignorance regarding psychoneurotic disturbances, or because of doubts as to their cause or genuineness in individual cases, an employer may be reluctant to authorize a costly examination, or may attempt to provide only a limited kind of diagnosis. If the employer refuses, or if the employee is dissatisfied with the thoroughness or the conclusion of the employer's psychiatrist, he may of course consult a psychiatrist of his own choosing. But there is a possibility that the employee will not be reimbursed for this private examination; moreover, the responsibility for payment may often be difficult to ascertain in advance, particularly in the case of psychoneurotic reactions. ${ }^{42}$ In these circumstances, an injured workman may be reluctant to risk

37. Cf. English \& Finch 70-100; Noyes \& Kolb 130-69; Henderson \& Girlespie 89-106. A prognosis differs from a diagnosis in that the former includes only a forecast or estimate of the course, outcome, and duration of an illness, whereas the latter, although it may include a prediction of the future course of the reaction, is usually limited to a statement of the past and present conditions and experiences of the patient.

38. Freud, A., Child Observation and Prediction of Development, 13 Psxchoanalytic Study of THE CHILd 92-116 (1958).

39. The court's determination of the reasonableness of undergoing a psychiatric examination may be decisive on the incidence of employee refusal to submit to a psychiatric diagnosis, for it is generally held that an unreasonable refusal to submit to a medical examination will result in a denial of compensation, see, e.g., Cole v. Town of Miami, 52 Ariz. 488, 83 P.2d 997 (1938); 10 Sch NEIDER's TeXt § 2018.

40. See English \& Finch 70-100.

41. See, e.g., AlA. Cone tit. 26, § 293.

42. Several factors may cause the employee to hesitate in seeking further psychiatric diagnosis. Recognizing that "many persons think they need medical attention when in fact they do not," Lowman v. Amphitheatre School District No. 10, 56 Ariz. 516, 517-18, 109 
incurring a large expense for diagnosis. Some workmen's compensation statutes allow the administrative board to call in impartial medical witnesses at the state's expense. ${ }^{43}$ This procedure might remedy some of the problems when insufficient psychiatric data is presented. Whether this alternative can provide a satisfactory solution to the problem will depend on several factors-the cost of reliable diagnosis when state personnel are used, ${ }^{44}$ the number of cases in which such additional testimony is needed, and the amount of funds available.

\section{The Physical Impact or Injury Rule}

Some legislatures and courts have imposed an additional barrier to recovery in the form of a physical impact or injury requirement. This rule, in force in a diminishing number of states, does not allow compensation for psychoneurotic reactions unless the disturbance is the result of some "physical" impact on the body, or unless the resulting injury can in some sense be defined as "physical." 45 Thus, in jurisdictions where the rule is still adhered to, a psychoneurosis unaccompanied by either contemporaneous physical impact or resultant physical injury will be held non-compensable. ${ }^{46}$ For example, in Bekeleski v. O.F. Neal

P.2d 617, 618 (1941), some courts have held that the cost of medical examination and treatment may be recovered even though the injury did not result in either a temporary or permanent disability; but they have limited the amount of medical expenses that may be recovered in such cases to those "necessarily incurred" as a result of the accident. Lowman v. Industrial Comm'n, 54 Ariz. 413, 96 P.2d 405 (1939) and Lowman v. Amphitheatre School Dist. No. 10, 56 Ariz. 516, 517-18, 109 P.2d 617, 618 (1941). Furthermore, reimbursement of medical expenses, including the cost of examination and diagnosis, generally will not be ordered if the injury did not arise out of and in the course of employment. See, e.g., Industrial Indem. Co. v. Industrial Acc. Comm'n, 103 Cal. App. 2d 249, 229 P.2d 2 (1951), Owsiejko v. American Hardware Corp., 137 Conn. 185, 75 A.2d 404 (1950). Since proof of the causal relationship between the employment and the psychoneuroses may be difficult in many cases, see notes 101-05 infra and accompanying text, and since the symptoms which an employee suffers may not constitute a disability (indeed they may be held not to constitute an injury), the employee may not be able to recover the cost of the psychiatric diagnoses which he procures on his own initiative. Because of the time needed for adequate diagnosis this cost may be considerable.

43. See, e.g., AlA. Code tit. 26, $\$ 293$.

44. Although the cost of using a staff psychiatrist on salary to the state may appear to be small, the real cost may be in the strain it places on other institutional needs.

45. Generally, courts will allow compensation for a psychoneurotic reaction if it was preceded by a physical impact. See, e.g., Redfearn v. Sparks Withington Co., 353 Mich. 286, 91 N.W.2d 516 (1958) ; Buck \& Simmons Auto \& Elec. Supply Co. v. Kesterson, 194 Tenn. 115, 250 S.W.2d 39 (1952). Those denying compensation have generally held that the claimant has failed to establish a causal connection between the injury and psychoneurosis. See, e.g., Miller Rasmussen Ice \& Coal Co. v. Industrial Comm'n, 263 Wis. 538, 57 N.W.2d 736 (1953) ; Quillen v. O. D. Purington Co., 80 R.I. 165, 94 A.2d 247 (1953). In addition, courts have generally allowed compensation where physical injuries result from a mental stimulus, such as fright or excitement. See, e.g., Hall v. Doremus, 114 N.J.L. 47, 175 Atl. 369 (1934) ; Roberts v. Dredge Fund, 71 Ida. 380, 232 P.2d 975 (1951) ; Egan's Case, 116 N.E.2d 844 (Mass. 1954). Contra, Toth v. Standard Oil Co., 160 Ohio 1, 113 N.E.2d 81 (1953).

46. See, e.g., Chernin v. Progress Serv. Co., 9 App. Div. 2d 170, 192 N.Y.S.2d 758 (1959) (denial of award to taxicab driver for aggravation of a repressed schizophrenia due 
Co.,47 the Nebraska court, applying a statute which defined injury as "only violence to the physical structure of the body," 48 held that the "language indicates a clear distinction between physical and bodily injury on the one hand, and mental, nervous, and psychiatric injury unaccompanied by violence to the physical structure of the body on the other." 49 The court denied compensation to an elevator operator who had been in an elevator for thirty minutes with a dying man. The claimant had sustained no physical injuries, but was unable to perform her work because of a psychoneurosis. A similar result was reached in City Ice \& Fuel Div. v. Smith. ${ }^{50}$ The claimant suffered a jolt when a passing car sideswiped his truck, and four days later he went into a stupor which was diagnosed as "conversion hysteria" 51 and possible "dementia praecox, catatonic type." 52 The Florida court, limited by the statutory provision that "a mental or nervous injury due to fright or excitement only ... shall be deemed not to be an injury by accident arising out of the employment," absence of physical trauma defeated the plaintiff's claim.

On the other hand, several courts have followed a British precedent ${ }^{64}$ in allowing compensation. Bailey v. American Gen. Ins. Co. ${ }^{55}$ involved an ironworker who saw a fellow employee plunge to his death when a scaffold on which they had both been working gave way. The claimant himself had been able to swing to safety. Although he did suffer bruises, they were minor, healed within a short time, and did not "cause or contribute to any disability." "Br But he did develop an anxiety reaction and was unable to continue as an ironworker. Operating under a similar statutory definition as that in Bekeleski, the court construed the phrase "damage or harm to the physical structure of the body"57 as meaning a failure of the body to function properly. The court ex-

to emotional strain of police investigation of a minor traffic accident). Contra, Burlington Mills Corp. v. Hagood, 177 Va. 204, 13 S.E.2d 291 (1941) ; Simon v. R.H.H. Steel Laundry, 25 N.J. Super, 50, 95 A.2d 446 (Hudson County Ct.), aff'd, 26 N.J. Super. 598, 98 A.2d 604 (App. Div. 1953). For a review of cases on this point, see Carter v. General Motors Corp., 361 Mich. 577, 106 N.W.2d 105 (1960).

47. 141 Neb. 657,4 N.W.2d 741 (1942).

48. Neb. Rev. Stat. ANN. § 48-151(4) (1943).

49. $141 \mathrm{Neb}$. at 660,4 N.W.2d at 743 .

50. 56 So. 2d 329 (Fla. 1952).

51. Conversion hysteria is the term formerly used to describe the symptoms of conversion reaction. See Psychiatric Manual 33.

52. This term, which is equivalent to the more widely favored term "catatonic schizophrenia," represents a group of psychotic reactions generally "characterized by fundamental disturbances in reality relationships and concept formations. . . . Conspicuous motor behavior, exhibiting either marked generalized inhibition ... or excessive motor activity and excitement" characterize the catatonic type of schizophrenia. Psychiatric Manuar 26.

53. Fla. Stat. AnN. \$ 440.02(19) (1952).

54. Yates v. South Kirby \& Co. Collieries, Ltd., [1910] 2 K.B. 538 (a mine worker who developed a disabling psychoneurotic reaction after aiding a dying co-employee was granted compensation).

55. 154 Tex. 430, 279 S.W.2d 315 (1955).

56. Id. at 432 .

57. Tex. Rev. Civ. Stat. Ann. art. 8306(20). 
pressly refused to make a distinction between physical and mental injuries. ${ }^{58}$ In Charon's Case ${ }^{59}$ where the issue was the physical nature of the causal factor, a statute which required "personal injury"60 arising out of and in the course of his employment was held not to exclude a disability "merely because the injury was not occasioned by physical impact or the application of some form of external violence to the body." 61 The claimant suffered from a conversion reaction in the form of a paralysis of her left side as the result of fright occasioned by a loud noise and flash of light created when lightning struck the building in which she was working.

The separate category reserved for "physical" injuries has little support in psychiatric theory, which regards man as an integrated being. ${ }^{62}$ The rule is sometimes rationalized, however, by appeal to administrative considerations. It is contended, for example, that the "physical" injury requirement will guarantee the genuineness of the claim. ${ }^{63}$ But use of this rule as a protective device places a heavier burden of proof on those suffering from mental disturbances without any basis for such a distinction. In fact, conscious simulation of the often complex patterns of psychoneurotic reactions may be easier to detect than certain feigned "physical" injuries such as whiplash or back injury. ${ }^{64}$ While detection of falsified claims may be made difficult if the testimony of medical witnesses is partial or perjured, this danger seems no less present in cases where there has been a physical impact or injury.

Similarly, the requirement of a physical impact cannot be justified as a safeguard to ensure that there is a cause-in-fact relationship between injury and employment. ${ }^{65}$ Non-physical factors can precipitate a neurotic disturbance as readily as physical factors, perhaps even more readily. ${ }^{66}$ Moreover, the presence of a physical impact does not make the fact of cause any easier to establish. The

58. $154 \mathrm{Tex}$ at 440 .

59. 321 Mass. 694, 75 N.E.2d 511 (1947).

60. MLAss. Ann. LAws ch. 152, §526 (1957). ("If an employee ... receives a personal injury arising out of and in the course of his employment ... he shall be paid compensation.")

61. 321 Mass. at 695,75 N.E.2d at 512.

62. See, e.g., Kubie, The Neurotic Process as the Focus of Physiological and Psychoanalytic Research, 104 Journal of Mental ScIence 518 (1958); Menninger, PsychiatRY IN a Troubled World 163 (1948); Diethelm, Introduction to TreatMent in Psychiatry (1950); Strecker, Practicar Clinical Psychiatry 430 (7th ed. 1957).

63. The belief that physical injury is necessary to ensure the genuineness of the claim stems from early tort decisions. See, e.g., Mitchell v. Rochester Ry., 151 N.Y. 107, 109, 45 N.E. 354, 355 (1896) ; Kalen v. Terre Haute \& I.R.R., 18 Ind. App. 202, 206, 47 N.E. 694, 697-98 (1897). This argument has been rejected, however, in many cases. See, e.g., Chituchiolo v. New England Wholesale Tailors, 84 N.H. 329, 336-37, 150 Atl. 540, 543 (1930).

64. Wechsler, The Neuroses 246 (1929); Keschner, Simulation (Malingering) In Relation to Injuries of the Skall, Brain and Spinal Cord, in INJURIEs of tae SkuLL, Brann and Spinal CoRd 342-68 (Brock ed. 1943) [hereinafter cited as Keschner] (presenting several devices for detecting malingering of various mental disorders).

65. See, e.g., Chiuchiolo v. New England Wholesale Tailors, 84 N.H. 329, 336-37, 150 Atl. 540, 543 (1930).

66. See, e.g., Guttumacher \& Weinofen, Psychintry and the Law 45 (1952) [hereinafter cited as GUTTMACHeR \& WeIHOFEN]; Dunne, The Psychiatrist and Compensation 
actual occurrence of an alleged stimulus should be relatively easy to ascertain, regardless of whether it involves physical impact or not. The crucial question is whether that particular stimulus precipitated the psychoneurosis, and that question involves a judgment as to the relationship between events and mental reactions-a judgment which is no more "tangible" when physical impact is involved than when it is not. ${ }^{67}$

Courts in deciding tort cases have recognized the ineffectiveness of the impact rule in establishing cause-in-fact and have undercut that requirement by allowing all but the most trivial of impacts to suffice. ${ }^{68}$ While the broadening of admissible "causes" seems desirable, the reluctance to consider trivial events suggests a mistaken view as to the nature of precipitating events. The courts apparently believe that the intensity of a stimulus is related to the likelihood that the stimulus was a cause of the psychoneurotic reaction. ${ }^{60}$ Psychiatrists believe that there is either no correlation between the intensity of the trauma and the resultant neurosis, ${ }^{70}$ or that the seriousness of the neurosis varies inversely with the severity of the triggering event. ${ }^{71}$

\section{The Accident and Causality Requirements}

In order for an employee to recover in a workmen's compensation case, he must establish that his disability occurred "by accident," arising out of and in

Neuroses, 1 BRIT. MEDical J. 427-29 (1953) [hereinafter cited as Dunne]; BRENd, Traumatic Disorders in Courts 23 (1938) [hereinafter cited as Brend]. See generally Pokorny \& Moore, Neuroses and Compensation: Chronic Psychiatric Disorders Following Injury or Stress in Compensation Situations, I Review of the Literature, 8 AMrerucaN Medicai Assoctation Archives of Industrial Hygiene and Occupational Medicine 547-63 (1953).

67. The emphasis on physical impact "overemphasizes one factor of stress with resultant understatement of other stresses and of the individual organism's propensity for breakdown." Modlen, The Trauma in Traumatic Neurosis, 1960 Menninger Clinic Bulletin 49. The disfavor among psychiatrists of the term traumatic neurosis, which literally means a psychogenic disorder shortly following a physical injury, is indicative of the belief that physical impact does not guarantee a significant "causal" relationship. Cf. Psycriatric MaNUAL 32. Various verbal formulae have been substituted for the phrase in an attempt to stress that a physical trauma is not a necessary or sufficient basis of a psychoneurotic reaction. Eliasberg, Challenge of Social Neutroses, 94 J. OF Nervous aNd Mental DisORDERS 676-87 (1941) uses the term "social neurosis." Kennedy, Mind of the Injured Worker: Its Effects on Disability Periods, 1 Conpensation Medicrne 19-24 (1946) [hereinafter cited as Kennedy], employs the phrases "neurosis following trauma" and "neurosis following accident"; Reed, Psychology of Tranma: Explanation and Classification of Attitudes of the Injured and Their Bearing on Compensation, 2 Industrial MEdicine 15761 (1933) refers to psychoneurotic reactions as "unconscious malingering"; and Ramsey, Nervous Disorder After Injury: Review of 400 Cases, 2 Brit. Medical J. $385-90$ (1939) [hereinafter cited as Ramsey], utilizes the concept of "justice neuroses."

68. Cf. Spade v. Lynn \& B.R.R., 172 Mass. 488, 52 N.E. 747 (1899) ; Morton v. Stack, 122 Ohio St. 115, 170 N.E. 869 (1930).

69. Cf. 2 HARPER \& JAMres, TorTs $\$ 18.4$, at 1034 (1956) [hereinafter cited as Harper \& JAMES].

70. See Ramsey, 385-90; Guttuacher \& Werhoren 45; Dunne 427.

71. See Kennedy 19-24; Noyes \& Kolb 514; BREND 23.

72. The phrase "by accident" is used in the majority of states. See, e.g., ALA. CoDE 
the course of employment."73 Most jurisdictions hold that the accident requirement is satisfied if either the cause of the injury was accidental or the injury itself was the unexpected result of the routine performance of the worker's duties. ${ }^{74}$ Several courts require, however, that the exertion or activity be unusual. ${ }^{75}$ In addition, many courts have held that the injury must be traceable to a reasonably definite time, place, occasion or cause. ${ }^{76}$ As part of the tendency to allow compensation in a greater number of cases, courts have expanded the several interpretations of the accident standard. The definiteness-of-time criterion, for example, has been extended so that a cause which operates over a period of several months satisfies the requirements. ${ }^{77}$ Similarly, the date on which the inability to work manifests itself has been held to satisfy the sudden result requirement, although it was preceded by a gradual and lengthy deterioration. ${ }^{78}$ And where the injury is precipitated by a series of events, courts have allowed compensation by categorizing each incident as a separate accident. ${ }^{70}$

Although the accident requirement in some form may be necessary for statute of limitations and other purposes, ${ }^{80}$ a strict application of the accident criteria as line drawing devices to separate compensable and non-compensable injuries will yield arbitrary results in cases of psychoneurotic reactions. ${ }^{81} \mathrm{~A}$ psychoneurotic reaction may not develop at a determinable date, ${ }^{82}$ and may be

ANN. tit. 26, $\S 253$ (1958) ; Del. Code ANN. tit. 19, $\S 2304$ (1953). Several statutes provide that the term injury shall mean phrase "accidental injury." See, e.g., CoNN. GEN. Stat. Ann. \& 31-139 (1960). A few states have no accident requirement in their basic coverage clause, but use the term elsewhere in the statute. The courts of these states have generally read the accident requirement into the coverage clause. See, e.g., Arnold v. Ogle Constr. Co., 333 Mich. 652, 53 N.W.2d 655 (1952) ; but see Texas Employers' Ins. Ass'n v. Mincey, 255 S.W.2d 262 (Tex. Civ. App. 1953).

73. See notes 87-100 infra and accompanying text.

74. See, e.g., Lewis v. Dept. of Law Enforcement, 79 Idaho 40, 311 P.2d 976 (1957); Carroll v. Industrial Comm'n, 69 Colo. 473, 195 Pac. 1097 (1921). The American decisions are based on an early English case. Fenton v. Thorley \& Co., [1903] A.C. 443, 448 (an accident is "an unlooked for mishap or an untoward event which is not expected or designed").

75. See, e.g., Seiler v. Robinson, 24 N.J. Super. 559, 95 A.2d 153 (1953) ; Contra, Lewis v. Dep't of Law Enforcement, 79 Idaho 40, 311 P.2d 976 (1957).

76. Hillerich \& Bradsby Co. v. Parker, 267 S.W.2d 746 (Ky. 1954); Gray's Hatchery \& Poultry Farms, Inc. v. Stevens, 46 Del. 191, 81 A.2d 322 (1950).

77. See, e.g., Walter v. Hagianis, 97 N.H. 314, 87 A.2d 154 (1952).

78. See, e.g., Kacavisti v. Sprague Elec. Co., 102 N.H. 266, 155 A.2d 183 (1959).

79. Ingalls Shipbuilding Corp. v. Byrd, 215 Miss. 234, 60 So. 2d 645 (1952); Aldrich v. Dole, 43 Idaho 30, 249 Pac. 87 (1926).

80. A specific date of injury, for example, may be necessary to determine such matters as which employer or carrier is to bear the risk, whether statutory amendments were in effect, or what wage basis applies.

81. See, e.g., Voss v. Prudential Ins. Co. of America, 14 N.J. Misc. 791, 187 Atl. 334 (Dept. Labor, Workmen's Comp. Bur. 1936) (Claimant, an insurance clerk was called an "idiot" by a fellow worker, and developed a nervous disability. The court denied compensation on the grounds that there was no accidental occurrence.).

82. See ENGLrSH \& FiNCH 163 ("The onset of [conversion reaction] . . symptoms 
triggered by a usual, expected event, ${ }^{83}$ occurring at a definite or indefinite time. ${ }^{84}$ Nor can the use of the accident standard in cases of psychoneurosis be justified as providing evidentiary value, or as aiding in determining the severity and permanence of the disability, preventing injury, or rehabilitating the worker. For example, the accident requirement does not facilitate proof of the existence of a psychoneurosis, since, as has been seen, the permanence and severity of a psychoneurotic injury do not depend upon the occurrence of an accident. ${ }^{85}$ Moreover, as is evident from heart attack cases, the accident criterion is too often misused as a means of avoiding an analysis of causation. ${ }^{80}$ Proof of a causal relation should be determined by criteria established for that specific purpose.

The causality requirement is generally embodied in the phrase "arising out of and in the course of employment." 87 The clause has been separated into two portions with "arising out of" referring to causality, and "in the course of" referring to the time, place and circumstances in which the accident occurs. 88 The application of both clauses to cases of psychoneurotic reactions, however, may yield unsatisfactory results.

"Arising out of employment" has been the fruitful (or fruitless) source of a mass of decisions turning upon nice distinctions and supported by refinements so subtle as to leave the mind of the reader in a maze of confusion. From their number counsel can, in most cases, cite what seems to be an authority for resolving in his favour, on whichever side he may be, the question in dispute. ${ }^{89}$

Because fault and the foreseeability of its consequences have no place in workmen's compensation law, the tort doctrine of proximate cause has been rejected. ${ }^{90}$ Instead, judges and commentators have tended to talk in terms of "risk." The accident is held to arise out of employment if a risk of that accident

is often dramatic, ... not infrequently, however, in the neurotically disposed individual the conversion symptoms gradually become evident .....").

83. See note 104 infra and accompanying text.

84. Dunne 427.

85. See notes $70 \& 71$ supra and accompanying text.

86. See 1 LaRson $\$ 38.80$ to .83 . But cf. Bollinger v. Wagaraw Bldg. Supply Co., 122 N.J.L. 512, 6 A.2d 396 (Ct. Err. \& App. 1939) (if the "arising out of" test has been satisfied, the "accident" requirement will also be deemed satisfied).

87. This phraseology is used in the majority of states. See, e.g., N.Y. WorknsEn's Comp. Law § 10; Irt. Ann. Stat. ch. 48, § 138 (Smith-Hurd 1960). But see UTak Code ANN. \$35-1-45 (1953) ("arising out of or in the course of employment"); W. VA. ConE ANN. § 2526(1) (1955) ("resulting from employment"). Several states have omitted the "arising out of" section. See, e.g., N.D. Rev. Code $\$$ 65-05-05 (1960); Texas Rev. Crv. Stat. Ann. art. 8306-3b (1956). The phrase "in the course of" has also been modified in several states. See, e.g., WIS. Stat. ANN. $\$ 102.03$ (1957) ("performing service growing out of and incidental to his employment").

88. See 1 LARSON $\$ \S 6.00,29.22$.

89. Herbert v. Samuel Fox \& Co., [1916] A.C. 405, 419.

90. See, e.g., New York Cent. R.R. v. White, 243 U.S. 188, 205 (1917). 
occurring was created by the employment situation. ${ }^{91}$ One commentator has attempted to categorize risks as: 1) clearly associated with the employment, 2) personal to the employee, 3 ) neutral (occurring at work but neither distinctly personal nor distinctly associated with employment), and 4) mixed (both a personal and employment cause).$^{92}$ These categories have little meaning, however. The fact that every accident occurs at work means that some part of the risk of injury can be attributed to the employment situation. The crucial issue is the kind or quality of risk which employment must create in order to satisfy the minimum requirement of legal causation.

Several different tests have been employed by various jurisdictions in determining what kinds of risks constitute a sufficient causal connection. The peculiar risk test, which has now largely been abandoned, requires that the kind of risk which results in injury be one which is peculiar to the employment situation and is not encountered by the general public. ${ }^{93}$ The increased risk standard, which replaced it in most jurisdictions, demands that the statistical probability of injury created by employment be greater than the risk experienced by the general public. ${ }^{04}$ A considerable number of states have gone beyond this standard, and, as a concomitant of a growing trend toward wider compensation, ${ }^{95}$ have accepted an actual or positional risk test which seems to require only cause in fact between the injury and employment, often expressed in terms of a but-for theory. ${ }^{90}$ Although usually undefined, "but-for" apparently means that if a given employment event had not occurred, the probabilities are great that the injury would not have happened. ${ }^{97}$ Unlike the others, this test is not a prospective comparison of the probabilities of injury, but is rather a retro-

91. See notes 93-100 infra and accompanying text.

92. 1 LARSON $\S \$ 7.00-.40$.

93. See, e.g., Industrial Comm'n v. Anderson, 69 Colo. 147, 169 Pac. 135 (1917); Wamboldt's Case, 265 Mass. 300, 163 N.E. 910 (1928) ; Star Publishing Co. v. Jackson, 115 Ind. App. 221, 58 N.E.2d 202 (1942) (compensation denied for neurosis on grounds that neurosis could occur in "countless occupations").

94. See, e.g., Cudahy Co. v. Parramore, 263 U.S. 418, 424-26 (1923); Finnegan v. Metropolitan Life Ins. Co., 162 N.E.2d 216, 222 (Ohio Ct. App. 1958).

95. See, e.g., Tinsman Mfg. Co. v. Sparks, 211 Ark. 554, 562-64, 201 S.W.2d 573, 57576 (1947) ; Texas Employers' Ins. Ass'n v. Holmes, 145 Tex. 158, 169, 196 S.W.2d 390, 394 (1946).

96. See, e.g., Crotty v. Driver Harris Co., 49 N.J. Super. 60, 139 A.2d 126, 133 (Super. Ct. 1958) ; Gargiulo v. Gargiulo, 13 N.J. 8, 97 A.2d 593 (1953) ; Harvey v. Caddo De Soto Cotton Oil Co., 199 La. 720, 6 So. $2 d 747$ (1942).

97. See, e.g., Crotty v. Driver Harris Co., supra note 96. ('Limitation on 'but for' is not related to the probabilities of the injury occurring qua injury, but to whether it is just as probable that the injury would have occurred somewhere else as at the time and place it did.") Several statements of the "positional" risk theory have been presented which go further in the direction of compensability. See, e.g., Kern v. Southport Mill, 174 La. 432, 438, 141 So. 19, 21 (1932) ("when one finds himself at the scene of an accident . . . because the necessities of his business called him there, the injuries he may suffer by reason of such accident 'arise out of the necessity which brought him there, and hence 'arise out of' his employment."). 
active comparison which includes all the peculiar facts giving rise to the actual accident. ${ }^{98}$

The but-for test, as well as the other tests, is often applied simultaneously with the principle that if a pre-existing disease or weakness is present and is aggravated or hastened to any extent by the employment, the resulting injury will be compensated in full. ${ }^{99}$ This approach has resulted in compensation being granted even when the statistical probabilities were quite high that the injury (or more accurately, a similar precipitating event) would have occurred in the absence of the employment-event. 100 Whenever courts following this rule categorize certain injuries as aggravations of pre-existing conditions, therefore, compensation is made to depend upon a lesser requirement of probable statistical correlation than is necessitated by the but-for test.

Unfortunately, the complex etiology of psychoneurosis and the demands of time for examination are such that in a substantial number of cases a psychiatrist will be unable to estimate with any degree of accuracy the probabilities of the injury occurring in the absence of employment. ${ }^{101}$ All major schools of psychoanalytic thought agree that although immediate factors of reality may serve as precipitating or exciting causes, the adult's predisposition towards a psychoneurotic reaction lies in the childhood. ${ }^{102}$ The existence within the unconscious of unresolved conflicts, aggression, unrecognized motivations, and repressed hostilities from childhood onward may create conflicts with which the ego is incapable of coping. The individual is then particularly susceptible to the production of a psychoneurotic reaction as a way of relieving any addi-

98. See, e.g., Harvey v. Caddo De Soto Cotton Oil Co., 199 La. 720, 727, 6 So. 2 d 747, 749 (1942) (the accident "need not have been foreseen or expected, but after the event it must appear to have had its origin in a risk connected with the employment, and to have flowed from that source as a rational consequence").

99. See, e.g., Ingalls Shipbuilding Corp. v. Byrd, 215 Miss. 234, 60 So. $2 \mathrm{~d} 645$ (1952). Cf. Geltman v. Reliable Linen \& Supply Co., 128 N.J.L. 443, 25 A.2d 894 (Ct. Err. \& App. 1942); Church v. Westchester Cty., 253 App. Div. 859, 1 N.Y.S.2d 581 (1938).

An attempt to apportion the responsibility for psychoneurotic reactions by determining the significance of the employment as a contributing factor would present an insurmountable task. In most cases a psychiatrist could not give a meaningful estimate. Even if this were not true, apportionment has not been favored, and only a few states have apportionment provisions which would be appropriate in this situation. See, e.g., Ky. Rev. Srar. ANN. \$ 342.005(1) (1955) ; N.D. Rev. CoDE \& 65-05-15 (1960). Apportionment, in the absence of statute, does not apply where the prior condition did not constitute a disability in the compensation sense. See, e.g., Eagle Indem. Co. v. Hadley, 70 Ariz. 179, 218 P.2d 488 (1950); O'Brien v. Manchester Yarn Mills, 95 N.H. 118, 59 A.2d 172 (1948).

100. Compare existing tort doctrine which measures the defendant's standard of conduct by the reactions of the "normal" person, unless the defendant has actual or constructive notice of plaintiff's hypersensitivity. The defendant's conduct must involve foreseeable risk of harm to a class of people which includes the plaintiff, e.g., Chiuchiolo v. New England Wholesale Tailors, 84 N.H. 329, 337, 150 Atl. 540, 544 (1930) ; Price v. Yellow Pine Paper Mill Co., 240 S.W. 588 (Tex. Civ. App. 1922) ; 2 HArper \& JaMres \$ 18.4, at 1035.

101. See generally Fenichel; English \& FINCH 70-100, 139-231.

102. See Noyes \& Kolb 76-86. See generally Fenichel; ENGLisH \& Fince 139-231. 
tion tension. ${ }^{103}$ Whether a given experience or combination of experiences will trigger the psychoneurotic potential into a psychoneurosis will depend on the vulnerability of the individual and the nature and duration of the stresses bearing upon him. ${ }^{104}$ In such cases, the causation requirement, whether in the form of the but-for or aggravated injury rule, is of little assistance in deciding whether to award compensation. Some causal connection with an employment event can probably be established in most cases, but since a constellation of factors is at work, it is freqeuntly impossible to determine the causal significance of any one factor. The coronary thrombosis cases, which have employed these criteria, illustrate the inappropriateness of applying either standard of causation to medical situations in which a single cause cannot be identified. Indeed, to follow the causal analysis of these heart attack decisions would be to enter a maze without a map, for they show no logical consistency. ${ }^{105}$

In those cases where cause-in-fact can neither be proven nor negated, the decision to grant or deny compensation should depend in large part upon the court's interpretation of the purpose of the causation requirement and the policies behind the workmen's compensation statutes. In this situation courts are confronted with several possibilities. First, in accord with the growing liberality of compensation and as a result of increased awareness of the indefinite origins of industrial injuries, the courts could allow compensation for all psychoneurotic injuries suffered by an employee for the reason that employment, like every other phase of the worker's environment, has in some measure contributed to his injury. Furthermore, imposition of higher rate costs on the employer could be justified in terms of the humanitarian purposes of shifting the risk, as between two innocent parties, to the one who can best bear or distribute the cost. ${ }^{100}$ Whether such increased costs constitute an actual burden upon the employer, or whether he can pass the cost on to consumers, suppliers, or employees, depends on a variety of factors, such as the employer's monopoly position, growth rate, stage of development, degree of competition between similar industries and their comparative accident costs, and the flexibility of output, demand, and resource supply. ${ }^{107}$ On the other hand, compensation could

103. Kubie, The Neurotic Potential, the Nentotic Process and the Nentrotic State, 2 United States Armed Forces Medical J. 1 (1951).

104. See, e.g., Kraines, The Therapy of the Neuroses and Psychoses 157 (1948); Saul \& Lyons, Acute Neurotic Reactions, in Dynamic Psychiatry 140 (Alexander \& Ross ed. 1952).

105. See 1 LARSON $\$ \$ 38.64,38.80$ to .83 .

105. See, e.g., Cudahy Packing Co. v. Parramore, 263 U.S. 418, 424 (1923) (the "equitable distribution of the economic burdens in cases of personal injury ... is a matter of sufficient public concern to escape condemnation as arbitrary, capricious or clearly unreasonable.").

107. See Calabresi, Sone Thonghts on Risk Distribution and the Law of Torts, 70 Y ALE L.J. 499 (1961). The cases, however, frequently assume that the cost of compensation can be passed on to the consumer, see Grain Handling Co. v. Sweeney, 102 F.2d 464, 465 (2d Cir. 1939), or to the employee or consumer, see Edwards v. Piedmont Publishing Co., 227 N.C. 184, 191, 41 S.E.2d 592, 597 (1947). 
be denied on the ground that the function of the causation requirement is to limit the employer's responsibility to those cases where the injury has a clear relationship to the employment. ${ }^{108}$ When employment is a relatively insignificant contributing factor, and the statutory requirement cannot be proven, it might be reasoned that the judiciary has no choice but to deny recovery. One additional factor which might weigh in favor of denying recovery when causation is not clearly proven is the fact that the employer must also bear the cost of therapy, directly or indirectly; the average cost of psychiatric therapy might be considerably greater than the average cost of curing other bodily injuries. ${ }^{100}$ Either granting or denying compensation could be accomplished within the framework of existing statutes simply by manipulating the burden of proof on the issue of causation.

The second part of the statutory formula_- "in the course of employment"refers to the spatial and temporal aspects of the events which cause the injury, 110 thus adding another facet to the "arising out of employment" requirement. Not only must the causal events be related to employment, but they must actually occur at times and in places which can be considered "at work."111 This statement seems superfluous to the general provision governing causation. ${ }^{112}$ Moreover, in an attempt to give meaning to this separate phrase by insisting on a precise and proximate connection to employment activity, courts have sometimes made very fine distinctions when determining which acts in a series of events are "causal." A Texas court, for example, denied compensation to a worker injured when a metal shaving which became lodged in his hair at

108. See, e.g., Star Publishing Co. v. Jackson, 115 Ind. App. 221, 58 N.E.2d 202 (1944).

109. The extent of the employer's obligation for medical treatment will depend on such factors as the statutory provisions, see, e.g., ALA. CODE tit. 26, $\$ 293$ (1958); see generally 10 ScHNEIDER's TexT $\$ \$ 2001-47$, the board's determination of whether psychotherapy or psycho-analysis is necessary, and the criteria for judging when the employee no longer needs treatment. The latter issue may raise particular difficulties in cases of psychoneurotic reactions, for psychiatric and legal concepts of "fitness" may be incompatible.

The possibility that the employee may refuse to undergo treatment raises additional problems regarding the cost of treatment. Generally where risks of harm from treatment are low and probability of cure high, refusal will terminate benefits. Lesh v. Illinois Steel Co., 163 Wis. 124, 157 N.W. 539 (1916), but where the risks of harm are high or the probability of cure is speculative, the claimant cannot be forced to undergo treatment. Melcher v. Drummond Mfg. Co., $312 \mathrm{Ky} .589,229$ S.W.2d 52 (1950). Although it is believed that psycho-analysis or psycho-therapy is effective in reducing both the intensity and the duration of the disability, see ENGLISH \& FINCH 139-231, subsections on treatment of psychoneurotic reactions, the psychiatrist may be unable to predict the degree or duration of disability that would have been eliminated by submission to treatment. Hence any denial of compensation on this ground would be based on mere speculation. Furthermore, in a case of psychoneurosis a worker may object to analysis or therapy on non-medical grounds, such as religious or moral beliefs, creating additional obstacles to applying the criterion used in cases of physical injuries.

110. See generally 1 LaRSON $\$ \$ 20.00-.22$.

111. See, e.g., Miller v. Bill Miller's Riviera, Inc., 21 N.J. Super. 112, 90 A.2d 889 (Super. Ct. 1952) ; Southern Cotton Oil Co. v. Bruce, 249 Ala. 675, 32 So. $2 \mathrm{~d} 666$ (1947).

112. See 1 LARSON $\S \S 29.00-.22$. 
work fell into his eye fifteen minutes after the close of working hours. ${ }^{113}$ Such attempts to isolate the causative event seem particularly inappropriate in cases involving psychoneurotic injury, since in those cases more than any other the chain of causation is likely to be tangled and complex.

\section{The Effect of Awarding Compensation}

\section{Effect on Hiring Practices}

One result of awarding compensation for psychoneurotic reactions may be that employers, whose insurance rates are generally based on the accident record of their employees, ${ }^{114}$ will exclude potential psychoneurotics, as they now exclude certain types of epileptics, from assuming gainful employment. ${ }^{115}$ At present, the threat to the worker is probably minimal. Since most persons who are vulnerable to forming a psychoneurotic reaction as a result of an industrial accident appear "normal" when hired, ${ }^{116}$ the use of screening devices would be necessary to detect potential psychoneurotics. Whether the use of such tests is feasible will depend upon their predictive ability ${ }^{117}$ as well as the particular needs of the employer. Such factors as the labor supply available and the administrative cost of testing may well outweigh the expense of increased insurance rates. Even if screening devices were feasible, the financial motive for excluding potential psychoneurotics from employment could be met by placing the burden of liability for psychoneurotic reactions upon a special fund which would be financed by a uniform rate of contribution from all employers, perhaps fashioned after the second injury fund now used in almost all workmen's compensation systems. ${ }^{118}$

113. American Motorists Ins. Co. v. Steel, 229 S.W.2d 386 (Tex. Civ. App. 1950).

114. For a discussion of the general mode of rate making, see Wisconsin Compensation Rating and Inspection Bureau v. Mortensen, 227 Wis. 335, 277 N.W. 679 (1938); State cx rel. Minnesota Employers' Ass'n v. Faricy, 236 Minn. 468, 53 N.W.2d 457 (1952); SOMIERS \& SOMIERS 102-10.

115. A similar problem has arisen in connection with nonapportionment of liability for handicapped workers. For example, it has been estimated that requiring the employer to bear full responsibility for total disability for loss of a worker's remaining arm, leg, or eye, resulted in the displacement of approximately 7,000 to 8,000 "one-eyed, one-legged, one-armed, and one-handed men" in Oklahoma. 2 LARson $\$ 59.32$, citing U.S. B.L.S. Bull. No. 536 [1931] at 272, statement by I. K. Huber.

116. Kubie, The Fundanental Nature of the Distinction Between Normality and Ncurosis, 23 Psychoanalytic Quarterly (1954).

117. See generally Rapaport, Diagnostic Psychological Testing (1945).

118. A second injury fund "makes the employer ultimately liable only for the amount of disability attributable to the particular injury occurring in his employment, while the fund pays the difference between that amount and the total amount to which the employee is entitled for the combined effects of his prior and present injury." 1 LARson $\$ 59.31$, at 59. New York has used several types of special funds to meet various contingencies. See, c.g., N.Y. WorkMren's ConIP. LAW § 25 (a) (Fund for Reopened Cases); § 15(9) (Vocational Rehabilitation Fund). 


\section{Prevention of Injury}

The effect of the compensation award in relation to the goal of injury prevention should also be considered. In the usual industrial injury case, the increase in the employer's insurance rates may induce him to adopt means by which the risk of in jury will be reduced. ${ }^{119}$ This will not be true in most cases of psychoneuroses, however, since the events which will trigger a psychoneurotic reaction vary with the indivdual and probably cannot be accurately predicted and prevented. ${ }^{120}$

Arguably, the availability of compensation may tend to increase the rate of psychoneurotic injury by contributing to the formation of the psychoneurotic reaction. Many different external and internal factors may precipitate a psychoneurosis. The basic factor is a threat from within the personality-the individual's need to relieve unconscious fear or guilt. ${ }^{121}$ In Freudian terms, when repressed id ${ }^{122}$ impulses threaten to discharge into consciousness and can no longer be repressed, the ego, ${ }^{123}$ in order to reconcile the demands of the instinctual id impulses with reality and conscience, attempts by symptom formation to reach the best possible compromise solution among competing interests. ${ }^{124}$ By allowing the least harmful release of psychic tension, the ego attains a real advantage which is termed the "primary gain" of the psychoneurotic illness. ${ }^{125}$ In some cases, external advantages may contribute additional unconscious motives for falling $\mathbf{1 1 1} .^{126}$ For example, one psychiatrist has stated that the development of an anxiety state by a soldier in combat "may be unconsciously influenced by the knowledge that it will lead to removal to safety."127

119. See note 10 supra and accompanying text.

120. Of course, the employer may, in certain instances, be able to prevent the precipitation of a psychoneurosis in a person whom he knows is under severe stress or is not well adapted to his job, by lessening the employee's work load or by moving him to another position.

121. See Brenner 211.

122. The id, a part of the unconscious, is the reservoir for all psychic energy and is the source of instinctual drives. According to Freud, "it has no organization and no unified will, only an impulsion to obtain satisfaction for the instinctual needs, in accordance with the pleasure-principle." Hinsie \& Campredr 362, quoting Freud, New Introductory Lectures on Psycho-Analysis (Sprott trans1. 1933).

123. See note 15 supra.

124. BRENNER 211.

125. Ibid.

126. See Freud, 7 Standard Edition of the Complete Psychological Works 43 (Strachey transl. 1953):

In every neurotic illness a primary gain has ... to be recognized. In the first place, falling ill involves a saving of psychical effort; it emerges as being essentially the most convenient solution where there is mental conflict .... This element in the primary gain may be described as the internal or psychological one, and it is, so to say, a constant one. But, beyond this, external factors, (such as . . . the situation of a woman subjugated by her husband) may contribute motives for falling ill and these will constitute the external element in the primary gain.

But see Saul \& Lyons, supra note 104, at 155-56.

127. BRENNER 212. Brenner limits this theory, however, by noting that "there are many 
Little psychiatric data has been found relating to the question of whether financial gain can provide such a motive. In all probability, an assessment of the respective roles of the wish for monetary gain and other unconscious mechanisms would be a virtually impossible task. Even assuming, as is probably the case, that the prospect of compensation does provide an additional motive in some cases, ${ }^{128}$ whether and how often it would have a dispositive effect on borderline cases is still speculative. Furthermore, there is no reason to believe that an unconscious motivation for remuneration has any different effect in cases of psychoneurosis than it has in typical industrial accident cases caused by lack of care on the part of the employee. ${ }^{129}$

\section{Employee Rehabilitation}

The receipt of financial aid may affect the duration of the psychoneurotic reaction and may therefore be incompatible with the aim of rehabilitating the employee. As has been seen, the individual has developed the psychoneurotic reaction in order to achieve the best possible adaptation to his environment. But he has not resolved his underlying psychic conflict and hence the continuation of the psychoneurotic reaction is necessary to prevent the re-emergence into consciousness of the repressed id impulses. This defensive operation of the ego is the primary factor sustaining the psychoneurotic reaction. In addition, however, external benefits, such as the receipt of sympathy, attention, or compensation may unconsciously aid in prolonging the reaction and perhaps even heightening its intensity. ${ }^{130}$ Two basic reasons are presented by psychiatrists to explain the significance of such factors. First, the external benefits may help the individual to adapt to his psychoneurotic reaction. The receipt of compensation may satisfy dependency or aggressive needs. It may also reduce financial worries resulting from the psychoneurotic reaction, thus reinforcing the effectiveness of the reaction as a conflict-reducing device. ${ }^{131}$ Second, many psychiatrists accept the view that such external benefits may constitute advantages

cases in which there is no question of such a possibility and in which the neurosis comes to have a certain value to the individual only after its development." Ibid.

128. See Noyes \& Kols 514.

129. It is generally assumed by psychiatrists that an accidental mishap which is caused by the individual's own actions is the result of an unconscious intent to produce the accident as a means of at least partially satisfying such elements as aggression, dependency or punition. Brenner 150-57; Menninger, Man Against Himself 278-94 (Harvest Book ed. 1959).

130. See, e.g., Alexander, Fundarrentals of Psychoanalysis 212-13 (1948) [hereinafter cited as ALEXANDER] ("emotional and financial gains derived from illness contribute to the prolongation of illness"). Keschner 343 ("the clinical picture following an accident in which legal liability is involved varies strikingly from that following a similar accident in which the injured person claims no compensation or damages for negligence").

131. FENICHEZ 126-27 ("Obtaining financial compensation or fighting for one creates a poor atmosphere for psychotherapy, the more so if the compensation brings not only rational advantages but has acquired the unconscious meaning of love and protecting security as well." 
which are independent of those associated with the release of psychic tension. A desire to retain these bonuses may unconsciously motivate the individual to prolong the psychoneurotic reaction once it has arisen. ${ }^{132}$ The receipt of compensation is frequently cited as an example of this form of secondary gain. ${ }^{133}$

Despite an awareness of the ramifications of granting compensation on the rehabilitation of the employee, courts have generally failed to consider the alternatives open to them to minimize the adverse psychological effect of the award, and have usually granted continuous payments, if all other criteria for compensation have been satisfied. ${ }^{134}$

As a solution to this compensation-rehabilitation dilemma, lump sum payments which cannot be appealed or modified have been suggested on the belief

132. Hendricks, Facts and Theories of Psychoanalysis 235-36 (1958) (" 'Secondary gain' comprises the secondary benefits which people with neurosis strive to obtain from their symptoms . . . 'Secondary gain' is the result of the effort to win from the neurosis itself a 'bonus,' consisting in additional pleasures which could not be obtained without it"); BRENNER 211-12:

The secondary gain is merely a special case of the ceaseless efforts of the ego to exploit the possibilities for pleasurable gratification which are available to it. Once a symptom has been formed, the ego may discover that there are advantages which the symptom brings with it. . . From the point of view of their treatment, . . . [secondary gains] may result in the fact that the patient unconsciously prefers to keep his neurosis rather than to lose it, since his symptoms have become valuable to him. The treatment of severe obesity, for example, is always a difficult matter, but it becomes impossible if the patient is a fat lady in a circus, who makes her living from her illness.

These psychiatric statements are based on clinical observations and not upon statistical studies. Although few surveys have been conducted on this point, studies on similar issues tend to corroborate the psycho-analytic position. See, e.g., Krusen \& Ford, Compensation Factor in Low Back Injuries, J. AxIERICAN Medical Ass'n (1958), in which 509 patients were studied for 5 years, $54 \%$ of whom were eligible for compensation, while $46 \%$ were not. Utilizing various control measures, the authors found that after treatment, $55.8 \%$ of the group receiving compensation were rated as improved, whereas $88.5 \%$ of those not receiving compensation were rated as improved. The observed difference in improvement between men who anticipated compensation and those who did not was $27.2 \%$, while the difference to be expected on the basis of chance was only $9.6 \%$.

133. See notes 130-31 supra. "Being incapacitated by illness may have certain advantages. Among the most transparent is financial compensation for accidents. . . These advantages retard recovery and make therapy particularly difficult." Alexander 212-13.

134. See, e.g., Simon v. R. H. H. Steel Laundry, Inc., 25 N.J. Super. 50, 95 A.2d 446 (Hudson County Ct. L. 1953) ; Murray v. Industrial Comm'n, 87 Ariz. 190, 195, 349 P.2d 627 (1960) ; Moses v. R. H. Wright \& Son, Inc., 90 So. 2d 330 (Fla. 1956).

Several courts have investigated the causal relation between the prolongation of a psychoneurotic reaction and its initial formation. Although some courts have denied compensation for the continuation of a psychoneurotic reaction, see, e.g., Swift \& Co. v. Ware, 53 Ga. App. 500, 186 S.E. 452 (1936), the majority has not viewed secondary gains as independent, intervening factors. See, e.g., Hood v. Texas Indem. Ins. Co., 146 Tex. 522, 209 S.W.2d 345, 347-48 (1948). The latter view is in accord with psychiatric theory, for secondary gains are an expected and usual result of the injury serving as an additional unconscious sustaining force, and are not a "substitution" for the initial need for the psychoneurotic reaction. 
that the receipt of a settlement which cannot be extended or discontinued will remove the monetary incentive for the employee unconsciously to prolong the duration of his disability. ${ }^{135}$ Although nearly every state workmen's compensation statute has a provision allowing lump sum payments, ${ }^{\mathbf{1 3 6}}$ the courts have not looked upon them with favor, for it is feared that an imprudent employee will waste the means provided for his support if he receives the money all at once. ${ }^{137}$ This objection could be met, however, by providing for periodic payments to the employee over a stated period of time in the future, with the payments not contingent on the worker's continued disability, and with the award not subject to reopening. ${ }^{138}$

A more serious flaw in this proposal, however, is the difficulty of predicting the duration of psychoneurotic disability. Determining the duration of a psychoneurotic reaction entails an evaluation of complex factors, many of which may change during the course of therapy. ${ }^{130}$ There is a substantial likelihood, therefore, that the psychiatrist's prediction, and hence the court's determination, of the length of disability will be wrong in any individual case. ${ }^{140}$ When the period for which compensation is awarded is greater than the actual period of disability, the employer may suffer a disproportionate increment in his rate schedule. On the other hand, this added cost may be canceled out by errors in the opposite direction, and by a general reduction in the cost of payments to those who are more speedily rehabilitated under this system. Even if individual employers do bear higher costs, the added charge may be a justifiable policy choice in favor of the rehabilitative goal, particularly if the costs can be spread.

But in those cases where the psychoneurotic reaction lasts beyond the estimated period of illness, the finality of the lump sum award will thwart the workmen's compensation goal of preventing destitution. A miscalculation, whether in terms of months or even weeks, can work a hardship on a disabled worker who is thereby left without compensation. Utilization of a loan plan in conjunction with lump sum payments might help reduce this conflict between the goals of rehabilitation and compensation. By permitting the employee

135. See, e.g., Fenichel 127; Huddleson, Accidents, Neuroses and Compensation $178-97$ (1932) ; Smith \& Solomon, Traumatic Neuroses in Court, 30 VA. L. REv. 87, 146 (1943) ; Miller, The Compensation Neurosis, 4 J. For. Scr. 159 (1959) ; Schaller, Psychoneurosis and Industry, 2 Occupational Medicine 183-89 (1946).

136. See, e.g., CaL. Labor Code Ann. $\S 5100$; Fla. Stat. AnN. $\S 440.20(9)$, (10). The courts or statutes generally require that the lump sum be in the best interests of either party, see, e.g., CAL. LABOR CODE, supra, or that the money be intended for a specific purpose, such as to pay a debt, McMullen v. Gavette Constr. Co., 207 Mich. 586, 175 N.W. 120 (1919), or to pay attorney's or physician's fees, Carr v. State Industrial Acc. Comm'n, 153 Ore. 517, 57 P.2d 1278 (1936).

137. See, e.g., Eagle Fluorspar Co. v. La Rue, 231 Ky. 757, 21 S.W.2d 1026 (1929).

138. Generally, payments are made periodically, but the employer, as well as the employee, can petition to have his case reopened for changed medical conditions. See, e.g., N.Y. WORKMEN'S COMP. LAW $\$ 15$.

139. See notes 37-40 supra and accompanying text.

140. Ibid. 
whose disability lasts longer than was anticipated to petition the board for a loan, destitution of the worker or his dependents could be prevented. Whether this program would reduce the incentive to unconsciously prolong the psychoneurotic reaction is open to question. Perhaps the desire to avoid repayment of the loan, once indebted, would be an equally great incentive to remain ill. ${ }^{141}$ In addition, such a plan would present numerous administrative difficulties, such as financing the fund, establishing criteria for granting the loan, and providing for collection and repayment.

In view of the difficulty of erecting a compensation scheme that will not impede rehabilitation, it seems preferable to retain the present system of payments. The goal of speedier rehabilitation will be better served by focusing on the process of therapy itself, by ensuring that provisions for treatment of compensable injuries are flexible enough to accommodate the often lengthy and expensive demands of psychiatric therapy. ${ }^{142}$

\section{Marilyn Cohent}

141. The continuous mounting of a debt during the course of therapy may very well work counter to the atmosphere needed for rehabilitation. Furthermore, if the employee died before he had discharged his debt, repayment of the loan might place an undue burden on his survivors at a time when they were financially least able to bear it. On the other hand, if his death cancelled the loan, this factor may serve as a strong incentive to the employee, particularly in the older age group, to remain ill.

142. In many states, see note 8 supra, this will necessitate a statutory change in the monetary limits and maximum periods in which the employer must provide for reasonable medical expenses.

$\dagger$ Third year student, Yale Law School. 